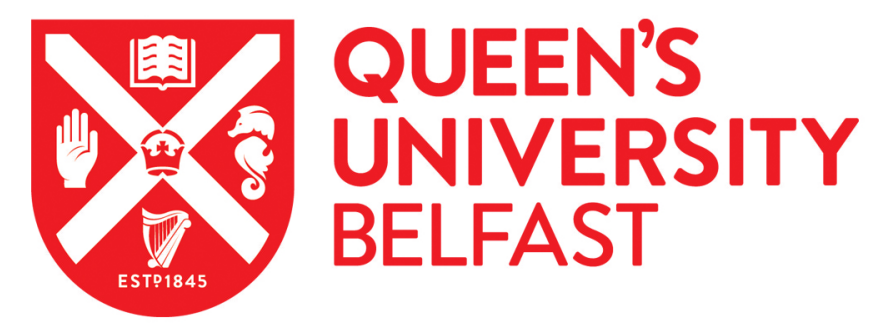

\title{
Para usted soy siempre yo: A Picaresque Double Act in Angeles Vicente's Zezé (1909)
}

Holloway, A. (2018). Para usted soy siempre yo: A Picaresque Double Act in Angeles Vicente's Zezé (1909). Bulletin of Spanish Studies: Hispanic Studies and Researches on Spain, Portugal and Latin America, 95(2-3), 205-222. https://doi.org/10.1080/14753820.2016.1253172

Published in:

Bulletin of Spanish Studies: Hispanic Studies and Researches on Spain, Portugal and Latin America

\section{Document Version:}

Peer reviewed version

Queen's University Belfast - Research Portal:

Link to publication record in Queen's University Belfast Research Portal

\section{Publisher rights}

(C) 2016 Bulletin of Spanish Studies

This is an Accepted Manuscript of an article published by Taylor \& Francis in

Bulletin of Spanish Studies on 29/11/2016, available online: http://www.tandfonline.com/10.1080/14753820.2016.1253172

\section{General rights}

Copyright for the publications made accessible via the Queen's University Belfast Research Portal is retained by the author(s) and / or other copyright owners and it is a condition of accessing these publications that users recognise and abide by the legal requirements associated with these rights.

Take down policy

The Research Portal is Queen's institutional repository that provides access to Queen's research output. Every effort has been made to ensure that content in the Research Portal does not infringe any person's rights, or applicable UK laws. If you discover content in the Research Portal that you believe breaches copyright or violates any law, please contact openaccess@qub.ac.uk. 


\title{
Para usted soy siempre yo: A Picaresque Double Act in Ángeles Vicente's Zezé (1909)
}

\author{
ANNE HOLLOWAY \\ Queen's University Belfast
}

\begin{abstract}
Y ¿cuál sería del papel de usted en esa obra dannunziana y maravillosa, que me es grato descubrir en el fondo de un corazón al que veo un poco desgarrado por hacer papeles en obras nada ideales?

-El de una sibila; un ser extraño, humano y sobrenatural al mismo tiempo.

-Sofía Romero me infunde un gran respeto bajo el delirio de ese papel que nunca representará probablemente; pero que revela un alma grande, disconforme, exaltada, llena de una fe dignificadora ...

¡Qué contraste entre lo que representa y lo que quisiera representar! ${ }^{1}$
\end{abstract}

In the introduction to his pivotal study Laws of Desire, Paul Julian Smith compares two Hispanic narratives of lesbian experience, one from the early sixties (Rosa Chacel, 'Transfiguración', first published in Mexico, 1961) and another from the early nineties (Terenci Moix, Garras de astracán [Barcelona: Editorial Planeta, 1991]). Smith underscores the potential inherent in the chance encounter, and the forced intimacy of travel in fostering an atmosphere of disclosure, given that Moix's narration takes place in the first-class cabin of a plane flying from New York to Madrid. ${ }^{2}$ The novella which is the focus of the present analysis, Zezé by Ángeles Vicente (1909), predates the publication of Chacel's 'Transfiguración' by over fifty years, and yet bears comparison to these later narratives of desire. It presents the colourful life story of a cupletista, as told to a fellow passenger

1 Carmen de Burgos \& Sofía Romero, Confidencias de artistas (Madrid: Sociedad Española de librería,), 139-40.

2 Paul Julian Smith, Laws of Desire: Questions of Homosexuality in Spanish Writing and Film 1960-1990 (Oxford: Oxford U. P., 1992), 3-4. 
in the course of an overnight boat journey from Buenos Aires to Montevideo. ${ }^{3}$ Recounting the social and sexual awakening of the irrepressible Emilia del Cerro, or 'Bella Zezé', the text is of interest as an early example of a femaleauthored depiction of same-sex desire, whilst its presentation as a record of a first-person narration to a single confidante also anchors it within a longer tradition in Spanish literature. I will argue that this novella expands the limits of the narrative conventions of the picaresque, rendering the 'freedom' its protagonist eventually encounters all the more significant.

Ángeles Vicente (b.1878) herself left Murcia for Argentina aged ten, returning to Madrid in 1906. Zezé's publication in 1909 followed her debut novel Teresilla in 1907, and during this period she also produced two collections of short stories, Los buitres (1908) and Sombras. Cuentos psiquicos (1910). Vicente's place in the literary panorama of early twentiethcentury Spanish literature has only recently begun to be considered, most notably since the Lengua de Trapo editions of Zezé (2005) and Sombras (2007) edited by Ángela Ena Bordonada. ${ }^{4}$ Montserrat Alás Brun has pointed to a gap in critical work on fiction by women from the early part of the twentieth century:

Parece haber un vacío en la narrativa escrita por mujeres desde Emilia Pardo Bazán hasta los años 30. Esta impresión contrasta con la constatación del éxito de novelistas como Carmen de Burgos y Concha Espina en su momento, y la visibilidad de ambas en los ambientes

3 Modernist writers were quick to capitalize on the potential of the new forms of travel; in her analysis of Modernist spaces, Mary Lee Bretz acknowledges 'Trains, Planes, Theaters and Cabarets' as sites for cross-cultural communication, and indeed amorous encounters. Some of the stories which explore the potential of these new spaces include Leopoldo Alas 'Superchería', Antonio Machado, 'En tren', Azorín, 'Los pueblos' and Pérez de Ayala, 'Tinieblas en las cumbres' (Mary Lee Bretz, Encounters across Borders: The Changing Visions of Spanish Modernism, 1890-1930 [Lewisburg: Bucknell U. P., 2001), 320-08.

4 Zezé was originally published by Librería de Pueyo y Fernando Fe, a prestigious editorial which disseminated the work of many notable literary figures of the early twentieth century. As well as her recent edition of Zezé, which includes a detailed introduction, Ángela Ena Bordonada has also edited critical editions of Vicente's collections of stories. See Ángeles Vicente, Zezé, estudio preliminar de Ángela Ena Bordonada (Madrid: Lengua de Trapo, 2005). All references are to this edition of the text. See also Ángeles Vicente, Los buitres, estudio preliminar de Ángela Ena Bordonada (Murcia: Editora Regional de Murcia, 2006) and Ángeles Vicente, Sombras. Cuentos psíquicos, estudio preliminar de Ángela Ena Bordonada (Madrid: Lengua de Trapo, 2007). A recent doctoral thesis by Sara Toro Ballesteros has presented a more complete picture of Vicente's corpus, in particular her short fiction, ordering, editing and analysing the short stories and articles published in newspapers and magazines. Toro Ballesteros' research has also brought to light valuable biographical information on the author. See Sara Toro Ballesteros, 'Viaje al mundo de las almas: la narrativa breve de Ángeles Vicente', doctoral thesis (Universidad de Granada, 2014). 
intelectuales de las primeras décadas del siglo XX. ${ }^{5}$

Recently however, the scholarship of Ena Bordonada, and latterly Sara Toro Ballesteros, coupled with studies which have sought to explore the margins of the 'Edad de Plata' have advanced our understanding of the perspective of this singular émigré and nuanced our picture of the cultural period to which she belonged. 6 In her most recent publication, Ena Bordonada offers a succinct summary of what is known to date of Vicente's biography and engagement in literary and artistic circles. She writes of her surprise when she initially discovered the work of this figure around 1990:

Me encontré con una buena escritora, que publica sus principales obras en el primer decenio del siglo XX, y cuya temática se reparte entre la crítica social, la defensa de los derechos de la mujer, el espiritismo, los registros de la mente, la literatura científica o ciencia-ficción y la erótica. Y además, pese a estos rastros tan sugestivos, era una desconocida. ${ }^{7}$

Vicente's corpus as a whole reveals her engagement with contemporary societal concerns, including reflections upon conditions in women's prisons, revealing a pronounced anticlericalism, and frequently expressing her dissatisfaction with women's education. She appears to have engaged with writers of popular erotic fiction, with Felipe Trigo providing the prologue for her first novel, Teresilla, in 1907. Recent evidence has also revealed her correspondence with Rubén Darío and Miguel de Unamuno. ${ }^{8}$

An awareness of the erotic potential of the picaresque frame amidst Vicente's contemporaries is evidenced in the existence of a series of illustrated erotic novellas published in Buenos Aires carrying the title 'la novela picaresca' which promised to deliver 'las mejores producciones del género picaresco y realista, extranjero y nacional'. Trigo is named alongside Zola and Azorín as

5 Montserrat Alás-Brun notes the persistence of the notion of a male 'Generación de 98': 'La tendencia a la revisión y expansión del canon del 98 (o de los movimientos finiseculares en general) dista de ser general todavía’ (Montserrat Alás-Brun, 'Las mujeres del 98 y el canon’, in Modernisms and Modernities: Studies in Honor of Donald L. Shaw, ed. Susan Carvalho [Newark: Juan de la Cuesta, 2006], 47-72 [p. 49]).

6 See for example La otra Edad de Plata: temas, géneros y creadores (1898-1936), ed. Ángela Ena Bordonada (Madrid: Editorial Complutense, 2013).

7 Ángela Ena Bordonada, 'Espiritismo, hipnosis y locura: los cuentos de Ángeles Vicente', in Los márgenes de la modernidad: temas y creadores raros y olvidados en la Edad de Plata, ed. Dolores Romero López (Sevilla: Punto Rojo Libros, 2014), 213-42 (p. 213).

8 Sara Toro Ballesteros, 'Esculpir la niebla: ocho cartas inéditas de Ángeles Vicente a Miguel de Unamuno', Journal of Hispanic Modernism, 2 (2011), 1-20, <http://www.modernismodigital.org/magazine.php?id=14>. Accessed 11th July 2014. 
a contributor. ${ }^{9}$

Zezé's publication roughly coincides with a series of 'real life' interviews with artists conducted by the pioneering feminist and journalist Carmen de Burgos, which were originally published in El Heraldo and later collected in two volumes in 1910. These included the last interview with Consuelo Bello, 'La Fornarina', the celebrated star of the cuple. ${ }^{10}$ It has been noted of the interviews in Confidencias de artistas that Carmen de Burgos herself never recedes into the background, the interviewer's sensibility consistently directing the reader's reception of the interviewee's testimony. ${ }^{11}$ To some extent, we might detect a shared objective in Vicente's and Burgos' fictional and non-fictional endeavours; indeed the dialogical nature of Zezé will be a key focus of the present analysis. Amidst Vicente's corpus, it was Zezés undeniable eroticism that initially attracted most commentary, to the author's disappointment:

Yo misma-y perdóneseme esta autocita—soy mas conocida por ese libro desenfadado y erótico que se llama Zezé que por la autora de Los buitres, alguno de cuyos cuentos ha sido traducidos a varios idiomas y merecido aplausos, que desde aquí agradezco, de prestigiosas firmas extranjeras. ${ }^{12}$

The text's explicit depiction of passionate sexual encounters between two young women represents one of the earliest examples of a female-authored portrayal of same-sex desire not only within Spain, but in the wider European context. ${ }^{13}$ It is not my intention to underplay this undeniably striking aspect of the text, but rather to consider how it may be mirrored in

\footnotetext{
${ }^{9}$ See, for example “\#7. Eduardo Zamacois. Amar a obscuras. La Novela Picaresca.pdf,” A Virtual Wunderkammer: Early Twentieth Century Erotica in Spain, accessed July 22, 2016, http://sicalipsis.humnet.ucla.edu/items/show/937.

10 In 1910 two volumes of these interviews were published as Confesiones de artistas, (Madrid: V.H. de Sanz Calleja, 1910) while later a single volume, with a prologue by Ramón Gómez de la Serna appeared entitled Confidencias de artistas.

11 See M. Dolores Ramírez Almazán, 'El lado más humano de la Diva en Confidencias de artistas de Carmen de Burgos’, in In corpore dominae: cuerpos escritos-cuerpos proscritos, ed. M. Dolores Ramírez Almazán (Sevilla: Arcibel, 2011), 171-221. See also José García Templado, 'Confidencias de artistas de Carmen de Burgos', Arbor, CLXXXVI (2010), 125-38.

12 Ángeles Vicente, review of El hipnotismo prodigioso by Alfredo Rodriguez de Aldao ('Aymerich'), Ateneo, 13:6 (1912), 272-74 (cited in Ena Bordonada, 'Espiritismo, hipnosis y locura’, 211).

13 Due to Zezé's recounting of her early erotic encounters, which include a frank depiction of an orgasm, the novella is rightly labelled 'pioneering' by Ena Bordonada. In European literature, the novel may have been preceded only by Idylle Saphique (1901) by Liane de Pougy. Gertrude Stein's QED appears to have been completed in 1903, although Stein suppressed this text until many years later.
} 
the relationship between picaresque narrator and author, and to suggest that Vicente may be knowingly framing her feminist critique of societal conventions with a clever play on literary tradition.

The potential of the picaresque mode as a vehicle for satire is well established, evident in the seemingly subversive drive of the early picaresque proto-novels which mercilessly exposed the hypocrisy of early modern Spanish society. None the less, it has been suggested that the more farreaching satirical effects are somewhat contained by the very conventions of the form. Writing on Quevedo's El Buscón, Edward Friedman points out that the text 'keeps the pícaro in his place', ultimately denying the possibility of social mobility. ${ }^{14}$ Zezés debt to the picaresque tradition is evident not only in its itinerant, self-reflexive protagonist and the explicit critique of society she articulates, but also in the fiction of a dialogical genesis present within the framing narrative. In the text most commonly cited as the foundational text of the picaresque genre (Lazarillo de Tormes [1554]) the protagonist apostrophizes an imagined reader, the shadowy 'Vuestra merced' who haunts the margins of the novella. Carroll B. Johnson foregrounds the nature of the power relationship inherent within confessional discourse, citing Foucault:

Foucault has observed that confessional discourse, of which picaresque is a subcategory, 'unfolds within a power relationship, for one does not confess without the presence (or virtual presence) of a partner who is [...] the authority who requires the confession ... the agency of domination does not reside in the one who speaks but in the one who listens and says nothing'. 15

Within the text's fiction, authority is vested in the 'Vuestra Merced' figure, who calls the text into existence, and beyond it, inevitably, authority lies with the 'real author'. Edwin Williamson has suggested that the freedoms granted the picaresque protagonist as the genre develops become ever more limited, noting the 'coercive grasp' of Francisco de Quevedo on his picaresque protagonist, Pablos, in La vida del buscón (1605). ${ }^{16}$ However Anne Cruz urges us to accept a distinct foundational text and a separate lineage for the female picaresque novel:

14 'For all its satirical effects and social critique, the narrative keeps the picaro in his place. The butt of the humour - and the victim of the irony —is, when all is said and done, the man whom the reader could presume to be in control. The very rhetoric that should be the ally of the narrator betrays him' (Edward H. Friedman, 'Trials of Discourse: Narrative Space in Quevedo's Buscón', in The Picaresque: Tradition and Displacement, ed. Giancarlo Maiorino [Minneapolis: Univ. of Minnesota Press, 1996], 183-225) (p.90)

15 Carroll B. Johnson, 'Defining the Picaresque: Authority and the Subject in Guzmán de Alfarache’, in The Picaresque: Tradition and Displacement, ed. Maiorino, 159-82 (p. 165).

16 Edwin Williamson, 'The Conflict between Author and Protagonist in Quevedo's Buscón’, Journal of Hispanic Philology, 2 (1977), 45-60 (p. 59). 
Although La vida de Lazarillo de Tormes - whose anonymous author was most certainly a man - has long been recognized as the progenitor of the male picaresque, the female picaresque derives from Fernando de Rojas' Tragicomedia de Calisto y Melibea, which became known by the name of its most famous character, the old go-between, Celestina. Published in its expanded version in 1500, this novel in dialogue form dwells as much on the picaresque lives of the servants as on the ill-starred lovers of its title. It is this lower-class stratum of the text, inhabited by the lascivious servants and the old bawd, that the female picaresque novels reconstruct as their milieu.

Critics are largely in agreement about the importance of dialogue in the origins of both traditions, and a shared concern is the somewhat vexed relationship between 'real' author and fictional narrator. Cruz would argue that the limitations placed by the author on the picaresque heroine are, if anything, even more apparent:

The freedom with which the pícara expresses herself is most evident in the narratives that are structured autobiographically, such as La picara Justina and, at least partially, La hija de la Celestina. Here, the male author not only creates a female character, but by narrating her life in the first person, he also assumes a feminine voice. Given the freedom he ostensibly allows her, the author would seem to partake of the character's unfettered outlook. Instead, the picara's discourse serves to reveal his manipulation and control, disclosing a relationship or repression between author and narrator. ${ }^{17}$

Friedman feels that Francisco Delicado's La lozana andaluza, however, 'points forward to the picaresque mode through an ambiguous prologue, rich in moral intention and challenged by the text proper, and through a doubling of the author, who becomes a character and a commentator in Lozana's story'. ${ }^{18}$ Indeed, some of the strategies he identifies within this early

17 Anne J. Cruz, 'Sexual Enclosure, Textual Escape: The Pícara As Prostitute in the Spanish Female Picaresque Novel', in Seeking the Woman in Late Medieval and Renaissance Writings: Essays in Feminist Contextual Criticism, ed. Sheila Fisher \& Janet E. Halley (Knoxville: Univ. of Tennessee Press, 1989), 135-60 (p. 136). Marcia Welles agrees with the lineage Cruz identifies: 'There is no doubt that the pícara has a past-nothing, after all, is created ex nihilo, and we can perceive prototypes in the Arcipreste's Trotaconventos, in Rojas's Celestina, in Delicado's Lozana Andaluza' (Marcia L. Welles, 'The Pícara: Towards Female Autonomy, Or the Vanity of Virtue’, Romance Quarterly, 33:1 [1986], 63-70) p. 63. Bruno Damiani also reads Lozana Andaluza as a forerunner to the picaresque, in 'La Lozana andaluza As Precursor to the Spanish Picaresque', in The Picaresque: A Symposium on the Rogue's Tale, ed. Carmen BenitoVessels \& Michael Zappala (Newark: Univ. of Delaware Press, 1994), 57-68.

18 Edward H. Friedman, The Antiheroine's Voice, Narrative Discourse and Transformations of the Picaresque (Columbia: Univ. of Missouri Press, 1987), 72; my emphasis. 
precursor of the picaresque text are instructive for understanding the mechanisms at work in Zezé-guiding the reader either to sympathy or to judgment. Zezé brings the fictional recipient of the narration out of the margins once again, and troubles the distinction between this figure and the author, since Zezé's cabinmate and confidante appears as a thinly veiled version of Ángeles Vicente herself. ${ }^{19}$ Indeed if we locate the text within a picaresque trajectory, its tone of protest becomes more pronounced, permitting its protagonist to transcend the somewhat vexed relationship with authority inherent within the very narrative structures of the genre. Zezé successfully appears as a collaborative endeavour between real author, implied author and picaresque protagonist. In a transparent relationship between speaker and implied author, the unnamed narrator's interjections confirm and consolidate the success of the cupletista's tale. To Zezé's playful reticence at the outset she responds:

- ¿Cree usted immoral descubrir las llagas y dolores ignorados por la multitud, que las grandes ciudades esconden en su colmena, ya entre el zumbido complejo de miles de energías renovadas, ya disimulados por los esplendores del lujo?

- Al contrario, muy moral, pero a los eunucos del viejo harén, conservadores de la corrupción, no les conviene entenderlo así.

While the text's focus on the individual struggles of a forgotten, though seething multitude, may offend some, the narrator blithely proclaims that she will absorb any criticism that may come her way ('No me preocupan' [p. 9 ). Despite the narrator's plea for brevity ('prefiero la narración concisa' [p. 9]) Zezé echoes the picaresque drive to provide an unstinting account in order to demonstrate how societal constraints may determine one's fate.

Friedman pointed to transformative approaches to the female picaresque in earlier twentieth-century Hispanic novels, including Elena Poniatowska's Hasta no verte Jesús mío (1969). This novel thematizes revision, presenting the text as a rewriting of the commentary of an informant. Friedman also acknowledges Erica Jong's novel, Fanny, Being the True History of the Adventures of Fanny Hackabout-Jones (1980) wherein Jong's eponymous heroine sets out to correct what she deems her misrepresentation by John Cleland in the notorious Memoirs of a Woman of Pleasure, commonly known as Fanny Hill (1748 and 1749). ${ }^{20}$ Friedman noted of Jong's text that 'Fanny's

19 The biographical correspondences between the narrator and Vicente have been noted by both Ena Bordonada ('Prologue' to Zezé, p. XIV) and Toro Ballesteros, 'Viaje al mundo de las almas' (29).

20 To some extent, similar metafictional devices are at work in more recent novels such as Michael Faber's The Crimson Petal and the White (2002) with Sugar's unflinching depiction of the realities of prostitution (and the novel itself) a bracing corrective to the objectifying More Sprees in London, a 'manual' for the Victorian gentlemen in search of prostitutes. 
diction belongs to the eighteenth century and her conscience to contemporary feminism'. ${ }^{21}$ While Zezé's diction is very much of her own time, Vicente's text might be understood as a fin-de-siècle recasting of the picaresque novel wherein the transformative social context, together with the buoyant emphasis on feminist debate, permits narrative constraints to be transcended.

None the less, to speak of adherence to a picaresque framework is not entirely unproblematic in the case of Zezé. Our heroine is not low-born, nor does the text truly confront poverty or squalor, despite Zezé's claim that her life has consisted of an oscillation between misery and opulence. While she enjoys traversing the 'barrios bajos' with the love interest known only as 'el estudiante', the pair appear to view themselves as mere intellectual tourists. However, in many other respects, Zezé's narration is structured as a picaresque tale, with its eponymous heroine recounting her life story to account for her present circumstance, specifically her profession as a cupletista.

The cuplé (or 'género infimo'), a narrative genre characterized by irreverence is arguably a natural bedfellow of the picaresque. ${ }^{22}$ Zezé does not romanticize her profession ('SSufré unas tantas humillaciones!' [page ref? p.7]) — citing a lack of good taste for the demise of the serious zarzuela (which she had effortlessly mastered-'[l]legando a la cumbre de mi carrera con pocas tropezones' [page ref? p.91]) and the rise of the 'género chico'. She notes the difficulties of earning a living 'decorously' in the absence of adequate education for young women in Spain: 'La mujer allí, comúnmente, tiene el cerebro atrofiado por la continua sugestion de obediencia que se le hace en la casa, en el colegio y en el confesionario' ( p. 7 page ref?). It would not be until 1911 that women would commonly attend variety performances: the presence of an overwhelmingly male audience and the bawdy content perhaps explain Zezé's resignation, indeed the narrative avoids confronting the details of this facet of her life. ${ }^{23}$ None the less, her profession generates

21 Friedman, The Antiheroine’s Voice, 203-19, p. 205. Erica Jong’s Fanny is also analysed in relation to the picaresque in James Mandrell, 'Questions of Genre and Gender: Contemporary American Versions of the Feminine Picaresque’, Novel, 20:2 (1987), 149-70, (pp. 166-67).

22 María Moliner defines the term as follows: 'Españolización del término francés couplet que se aplica a ciertas cancioncillas ligeras y, generalmente, picarescas, que se cantaban en el primer tercio del siglo XX en los espectáculos de variedades' Diccionario de uso del español (Madrid: Gredos, 2000), p. 404.

23 In Carmen de Burgos’ Confidencia de artistas most of the women interviewed indicate they pursued a career in performance out of necessity—very few seek to identify as artists through choice (see Ramírez Almazán, 'El lado más humano de la Diva en Confidencias de artistas. 18). Ana Cabello García also notes the expression of necessity as a constant in the portrayal of these women: 'La protagonista de Zezé confiesa que se hace cupletista por necesidad-esto es común a todas las cocotas’ (Ana Cabello García, ‘El escenario como espacio de libertad: la imagen de la 
the narrative in more ways than one: a cupletista is not deemed a suitable cabinmate by her fellow passengers, and, flustered, she is forced to change cabins several times before finding refuge with the narrator. ${ }^{24}$ Cruz has noted the compromised nature of the narrative space afforded the female picara, and the limitations of the text's seduction of its reader:

The licentiousness of the picara does not give her license to break away from authorial control: the protagonist remains at the service of the author, a seductive figure of speech ready to lure the reader into a maledominated and male-oriented discourse. ${ }^{25}$

The same case has been made of the protagonism inherent in the cuplé. Those who have studied popular culture from this era in depth tend to view the cuplé as conservative, ultimately reinforcing women's subordinate position despite the prominence and veneer of agency it offers. ${ }^{26}$ Serge Salaün, for example, argues that the cuplé reflects and emphasizes women as an instrument of male pleasure: 'sin acceder nunca a la responsabilidad ni a la madurez social y professional'. ${ }^{27}$ Anastasio, however, in her examination of the panorama in Barcelona disagrees with the dominant assessment of the genre's ideology, pointing out the cuplés potential as a vehicle for satirizing bourgeois expectations concerning women's behaviour:

[...] las canciones que comento, lejos de reproducir la ideología patriarcal capitalista, revelan una actitud más compleja de estas artistas hacia la

cupletista en las novelas de Fernando Mora y Ángeles Vicente [1909]', in Mujer, literatura y esfera pública: España 1900-1940, ed. Pilar Nieva-de la Paz, Sarah Wright, Catherine Davies \& Francisca Vilches-de Frutos [Philadelphia: Society of Spanish and Spanish-American Studies, 2008], 95-109 [p. 103]).

24 Pepa Anastasio provides examples of allusions to the dominant perception of the cupletista as a threat to conventional morality within the lyrics of the cuplé. In 'Mi debut en provincias' written by Consuelo Vello, 'La Fornarina', in 1912 the cupletista appears an unwelcome role model for the decent young provincial lady: 'Cuando voy a provincias / me suelen anunciar / en carteles muy grandes / por la localidad. / Las madres de familia / sienten gran inquietud / prohibiendo a sus hijas / la asistencia a mi debut. / Y si me ven pasar, / me miran con horror / y dicen en voz baja / con gran indignacion: / Es una indiana/ la llaman Fornarina, / ella sola alborota una ciudad / y a las gentes espanta / si sus canciones canta. / ¡Ya no hay Tranquilidad!’ (Pepa Anastasio, ‘Género ínfimo? El cuplé y la cupletista como desafío’, Journal of Iberian and Latin American Studies, 13:2-3 [2007], 193-216 [p. 203]).

25 Cruz, 'Sexual Enclosure, Textual Escape', 140-41.

26 Cabello-García observes a contrast in the portrayal of the possibilities of the cuplé as depicted by Vicente, and Fernando Mora whose Venus rebelde was also published in 1909. She argues that Mora presents a negative portrait of the the cupletista: 'La diferencia esencial radica en que la mirada masculina de Fernando de Mora lo toma como elemento censurable, frente a la opción que desarrolla Ángeles Vicente, como elogioso comportamiento por parte de la mujer' ('El escenario como espacio de libertad', 106).

27 Serge Salaün, El cuplé (1900-1936) (Madrid: Espasa Calpe, 1990), 79 (quoted in Anastasio, 'Género ínfimo?', 195). 
sacrosanta institución que supuestamente perpetúa el orden social establecido. ${ }^{28}$

The success and scandal surrounding double acts such as 'Las Argentinas' and 'Las Malagitas', in which one cupletista would play a male role, also points to the provocative potential inherent in the form.

While Zezé does not herself articulate belief in the potential of the cuplé as a vehicle for social commentary (indeed she suggests that economic success comes at the price of 'tantas humillaciones' [page ref? p. 7 ,) the picaresque certainly becomes an appropriate vehicle for reflections on the limitations of women's role in Vicente's hands, and pointed critiques are attributed to both narrators. ${ }^{29}$ Zezé muses, for example, that the nuns in the convent must be obliged to resign themselves to not thinking, so as not to suffer the constraints of the small-minded world they inhabit. In passing she also points out that prayer is degrading (and could not please God if we are made in his image), and that the conventions of social interaction are founded on hypocrisy, as she feigns anger at what was in fact a welcome kiss from Luis. Later the implied author laughs to hear young girls parroting the catechism without any understanding-reminding us that forms of female expression are always centre-stage within this narration.

The performer chooses to begin her episodic narration with the rupture of the parental relationship, the shattering of innocence accompanying the revelation of her mother's adulterous affair and her father's tearful revelation: 'Tu madre no te quiere' (page ref? p. 11). The picaro's (or picara's) epiphanic realization of their fundamental isolation in the world is a common feature of the genre. In the female picaresque we find prior examples of this realization couched in terms which reflect a loss of innocence, accompanied by a recognition that the mother is a sexual being, engendering resentment for the new lover. ${ }^{30}$ The first of a succession of guardian figures, her pious

28 Anastasio, 'Género ínfimo?’, 207.

29 Adela del Barco, who adopted the stage name 'La Bella Lulú' or 'Adelita Lulú', seems a potential model for Vicente’s creation Emilia del Cerro, 'La Bella Zezé'. The star was listed in Camilo Jose Cela’s Encyclopedia of eroticism: 'ADELITA LULÚ. Nombre de guerra de Adela del Barco, famosa canzonetista madrileña de principios de siglos, procedente del género ínfimo' (Camilo José Cela, Enciclopedia del erotismo, in Obra completa, 15 vols (Barcelona: Destino, 1982), XIV, 142.

30 For example, Friedman notes that Teresa de Manzanares’ expulsion from her mother's bed is presented as a turning point: 'Así se enlazó en ambos una firme amistad, que la obligó a hacer expulsión de mí, acomodándome a dormir en la cama de la criada, cosa que yo sentí en extremo, y aunque nina, bien se me traslució la causa por que se hacía aquella novedad conmigo, con lo cual tuve ojeriza al huésped, que no le podía ver delante de mis ojos, de suerte que su presencia me helaba en lo más sazonado de mi humor' (Friedman, The Antiheroine's Voice, 106). See Alonso de Castillo Solórzano, Teresa de Manzanares, natural de Madrid, in Novela picaresca 
maiden aunt uncovers the novel's strong seam of anticlerical sentiment, and Zezé's melodramatic language appears to reference knowingly the despair and petulance of her predecessors: 'si me tiene mas tiempo a su lado, me manda, de fijo al otro mundo' (page ref? p. 12). The aunt is herself a character with a racy past, a further nod in the direction of an emphasis on heredity at the outset, although Zezé merely hints at the details of her youth which are glancingly referenced as 'picantes y sabrosos' (page ref? p. 13). Before commencing her tale, in the framing narrative which functions as a prologue, Zezé unabashedly garners the interest of her listener by hinting at the piquant details contained within the narrative. Like all good picaresques her story will at least claim to be unflinching, and in some way scandalous:

[...] con mucho gusto se la contaré- y anadió riendo — no podrá usted publicarla.

— ¿Le molestaría?

-No, pero mi historia es de las que escandilazan a los moralistas. (page ref? p. 8)

Narration continues to be foregrounded when the tale is underway; early on we find Zezé entertaining the country children with tales of the city ('escuchaban extasiadas mis relatos' [page ref? p.22 ]). Her unguarded nature engenders an immediate intimacy which garners sympathy from the listener:

Doña Pasito, como llamaban a la dueña de la casa, conocía mi situación, por mí misma contada francamente apenas me familiaricé con ella. $\mathrm{Me}$ demostraba simpatía y me ofrecía su ayuda casi maternal, siempre que quisiera seguir su consejo, haciéndome cupletista; en lo que, aseguraba, obtendría tanto éxito como ella, que, a juzgar por su relato, era a cuanto se podía aspirar. (page ref? p. 61)

A ruthless instinct for self-preservation and survival, characteristic of a picaresque heroine also drives the narrative. At one point Zezé longs for the death of the sick young man she visits in the hospital in order to proceed with her ruse to save a young girl's honour, and any guilt she might feel is fleeting 'con unas lágrimas lavé mi conciencia' (page ref? p. 67). She is also more than willing to incriminate herself within her confessional narrative, revealing the somewhat callous seduction of her mother's lover Ferrario (arguably contributing to her mother's illness and death). Zezé confesses that her private reaction to Ferrario's suicide was ‘'Supremo cobarde, egoísta! ¿Por qué no lo hiciste antes de arruinarnos?' (page ref? p.40). She then relates her subsequent affair with both Leonor and her husband, the discovery of which leads to her destitution and complete isolation. At this moment Zezé

española, ed. Alonso Zamora Vicente, 3 vols (Barcelona: Editorial Noguer, 1974-1976), III (1976), 154. 
articulates the classic dilemma of the picaresque narrator: 'lo dificil era resolver el problema de la vida' (page ref? p. 59) only to find her choices are limited; she must succumb to a form of prostitution with the wealthy 'banquero' or tread the boards as a cupletista.

In recent years, as mentioned above, Zezé has attracted a certain amount of attention due in large part to the erotic episodes between the young Zezé and her classmate Leonor, an affair they later resume following Leonor's marriage. However, Bordonada resists classifying Zezé as a 'novela lesbiana', and even detects a current of anti-lesbian ideology within the text (prologue to Zezé, p. LV) Certainly the language Zezé employs regarding her attraction to Leonor ('la depravación'/locura') is evocative of shame; furthermore she hails the benefits of Leonor's removal from school as having a 'normalizing' effect on her and later we find an encroaching disenchantment with her repeated surrender to her lust for Leonor:

El tiempo pasaba, y continuaba sin interrupción los ratos de locura con Leonor. Cada vez, después de nuestras orgías, era mayor mi desencanto, mi cansancio de aquella novela vivida, donde se destacaba mi imagen más impura que lo que era, y más culpable que desgraciada. (page ref? p.45 )

There is also a clear sense that the pair enjoy the male gaze, that Zezé flaunts her status as 'demi-vierge' and at points presents her affair with Leonor as a mere initiation, a prelude which will come to fruition when she experiences her first kiss with Leonor's husband. However, on the same night that Zezé professes love for Luis she appreciatively comments upon the low necklines of the ladies at the ball. Zeze's erotic encounters with Luis, Leonor's husband or the 'estudiante' are certainly never relayed with the level of detail lavished upon those with Leonor, in particular the encounter in which Zezé's and Leonor's lust for one another is heightened by glimpses of their own reflection in the mirror. ${ }^{31}$ Arguably all affairs are fleeting within this text's emphasis on mobility, and frequently Zezé's erotic conquests are unnamed-being referred to merely as 'el banquero' and 'el estudiante', in keeping with picaresque convention.

Zezé's adolescent responses to Leonor's advances, which alternate

31 Angie Simonis' reading is more celebratory, situating the success of the novel in its dismantling of the stereotypes which abounded in male-authored portrayals of lesbian desire:_La novela de la época que más se acerca a la tradición lesbiana es Zezé (1909), de Ángeles Vicente, donde se nos brinda un retrato totalmente sorprendente y una vision nada estereotípica sobre las relaciones homoeróticas entre mujeres. Esta novela es la prueba temprana de que las estrategias contra el estereotipo social comenzaron casi simultáneamente a la creación de éste mismo por parte de la cultura hegemónica, aunque no tuvieran la misma suerte de difusión ni de influencia mediática’. Joaquín Belda’s La Coquito (1915) is cited by Simonis as a paradigmatic example of depictions of lesbian episodes as transient or experimental, merely serving the function of titillating the male spectator. Notably Belda's novel also deals with a cupletista. See Angie Simonis, 'Retratos en sepia: las imágenes literarias de las lesbianas a principios del siglo XX', in Ellas y nosotras, un diálogo a dos (Barcelona/Madrid: Egales, 2009), 13-35 (pp. 19-21). 
between unfettered desire and shame and remorse, are in fact a nuanced exploration of sexual awakening. As we have seen, the text turns upon a relationship between women-the implied author and the performative protagonist. The framing narrative actually mirrors the erotic affair between Zezé and Leonor in a number of aspects. As we have seen, the author places herself within the text as confidante, and subsequent willing participant in the verbal seduction of Zezé's explicit account. Indeed, storytelling is a key feature of the text's depiction of intimacy between women, recurrent in Zezé's depiction of her own adolescence. Leonor impresses her with tales of society life, eroding her innocence well before any physical consummation of desire: 'Iba descorriendo el velo de mi inocencia' (page ref? p. 24). Zezé's entire enunciation unfolds in an enclosed, intimate space, with both participants having undressed for bed, and there are early signs of the author's admiration for the statuesque, exotic figure and her desire to distance herself from the other passengers who have shunned the cupletista:

—iSi usted se queja tambien! ...

-Quejarme!

-Cómo soy cupletista!

-Y, Es ese su único delito?

-Esta noche no he cometido otro.

Comentando irónicamente lo sucedido, empezamos a desnudarnos.

(page ref? p.5)

Zezé's claim that she has 'fallen' because of a lack of alternatives ('si he descendido, no ha sido por mi culpa' [page ref? p.8]) is accepted even prior to her narration, although its universality is challenged, albeit gently ('Yo no he querido decir que usted pretenda justificarse, justificando; sino que, siendo usted buena, y habiendo caído por no tener otro remedio, crea que todos están en el mismo caso' [page ref? p. 8]) inviting the reader to reflect on the potentially far-reaching implications of the individual narration. We inevitably read Zezé's account through the lens of the narrator. When the perspective pulls back to the present day, she welcomes the performer's lack of inhibition, noting her embellishments as elegant examples of her status as a true entertainer: 'QQué curiosa mujer! ¡Que dificil era clasificarla! ¿Romántica, filósofa, histérica ...?’ (page ref? p. 81 NB. Missing inverted exclamation marks. Check) The intimacy between cupletista and narrator is consolidated during a break in Zezé's narrative when they overhear evidence of an illicit encounter, ironically involving one of the 'honestisimas señoras' who had complained about the suitability of the protagonist as a cabinmate. ${ }^{32}$ This shared experience mirrors an episode already related by Zezé wherein she and Leonor witnessed a nun receiving a male visitor. Leonor had chided

32 In Emilia Pardo Bazán’s 'Sud-Exprés' (1902), originally published in El Imparcial in 1902 and later in the 1909 collection of the story's title the narrator is a voyeur of an illicit embrace (Bretz, Encounters Across Borders, 322). 
her for her naivety, and the incident precipitated Leonor's seduction of Zezé. When the author-narrator jokingly suggests that the arrival of spring affects everyone, the possibility is raised that the pattern may be repeated.

Zezé deviates from the picaresque formula in its postscript, which takes cupletista to countess, eschewing the circularity identified by Guillén as a fundamental characteristic of the genre. ${ }^{33}$ At the beginning of her narration however, Zezé recalls Lazarillo, the archetypal picaro, having sacrificed 'respectability' for economic security. The text is more provocative in its intent, aiming ultimately to dismantle preoccupations with respectability and economic security. The determining factor in the narrative is the appearance of the author within the text, her gendering, and the basis of trust on which the narrative unfolds. The text recalibrates expectations, presenting us with a happily isolated figure at the close:

Busqué por todos los medios, que tanto el banquero, como Doña Pasito comprendieran que a un espíritu inquieto y rebelde como el mío, no le era dado a nadie, ni a mí misma, amoldar a su antojo, que para mí el lujo y el dinero era un aliciente; pero no constitutía mi felicidad. Yo necesitaba ser yo, libre, dueña de mi voluntad. (pp. 87-88)

Our emancipated (anti)heroine tests the boundaries of female selfrepresentation whilst laying bare the creative process and the relationship between author and protagonist. Vicente flatters the reader, inviting us to share the implied narrator's dismissal of rank and status. Whilst previously a plural subjectivity had been articulated by Zezé, alternating between the governance of her 'yo sentimental' her 'yo de lujuria' ( p. 44 page refs?) in the text's final dialogue we encounter a unified self-in the gaze of the other: ${ }^{34}$

—iQuerida señora!-exclamó Zezé, avanzando hacia mí con los brazos abiertos.

-Pero, ¿es usted? - contesté ingenuamente, correspondiendo al abrazo.

- Creo que sí, es decir, para usted soy siempre yo.

-No comprendo.

-Muy sencillo: si por ser cupletista no desmerecí ante usted, el hecho de ser condesa no me dará más valor.

- ¿Que tontería! Yo aprecio á la persona en sí, sin importarme el escalón social en que se encuentra. (page ref? p. 96)

33 Claudio Guillén, 'Toward a Definition of the Picaresque', in Literature as System: Essays toward the Theory of Literary History (Princeton: Princeton U. P., 1971), 71-106.

34 Gertrude Stein's The Autobiography of Alice B. Toklas (1932) is perhaps the most famous intersection of pseudo-autobiography and lesbian experience within modernism. Stein reimagines auto-biographical convention by writing her own life story in the voice of her life partner, Toklas. 
The observations of Marilyn Farwell, on lesbian narrative, as summarized by Rita Felski, are of value in seeking to understand Vicente's Zezé. Farwell endorses the notion that a story is not a neutral device - that plot patterns themselves carry their own weight of tradition, or cultural baggage: 'Farwell believes that feminists have often exaggerated the power of that form, portraying women as helpless victims of the tyranny of plot, struggling helplessly to free themselves from the meshes of age-old stories'. ${ }^{35}$ In recent years, innovative revisions of the picaresque mode in English literature have capitalized variously on the trappings of the genre, its promise of (mediated) 'access all areas' to captivate hordes of readers, and inevitably viewers, with highly successful television adaptations similarly playing their part in breathing new life into the mode. Neo-Victorian novels such as Michael Faber's The Crimson Petal and the White (2002) employ an omniscient narrator to facilitate this 'show all' and 'tell all' experience, taking the reader by the hand, reminding her/him (s)he is a visitor in the foreign country of the past. The device adds to the sense of a sojourn in a realm that is removed temporally as well as socially from the privileged reader the narrator addresses. However, Faber's novel also turns on the contrasting perspectives of Sugar, the upwardly mobile prostitute, and Agnes, the fragile Victorian wife, both framed as writers of their own life stories. Sugar's maturation as a writer is bound to her ascent towards respectability, a literary awakening unfolding alongside her progressive seduction by the lifestyle of the upper classes as she infiltrates the ranks of privilege. In Sarah Water's Fingersmith, also published in 2002, we find a nod towards a dual perspective-the narrative voice shifting between that of the seemingly sheltered mistress and her wordly servant, each deceiving the other even as they fall in love. Sarah Waters Tipping the Velvet (1999) also won critical acclaim for its careful reconstruction of Victorian sites like the music hall as counter-cultural spaces of potential. ${ }^{36}$

These later re-tellings may have the freed potential latent not only in the bohemian space of the music hall, but within the dialogical origins of the picaresque genre itself. In 1992, Paloma Díaz-Mas' successful historical novel

35 Marilyn Farwell, Heterosexual Plots and Lesbian Narratives (New York: New York U. P., 1996) (quoted by Rita Felski, Literature after Feminism [Chicago/London: Univ. of Chicago Press, 2003], 116).

36 On the publication of Water's bestseller, Mel Steel of The Independent questioned, 'Could this be a new genre? The bawdy lesbian picaresque novel?' Books: Fiction in Brief, The Independent, 22 ${ }^{\text {nd }}$ March 1998, p. 33. Waters has often reflected on her appropriation of the conventions of nineteenth-century fiction. See Jodie Medd, 'Encountering the Past in Recent Lesbian and Gay Fiction', in The Cambridge Companion to Gay and Lesbian Writing, ed. Hugh Stevens (Cambridge: Cambridge U. P., 2010), 167-84. Michael Faber's The Crimson Petal and the White also has a brief interlude in which Mrs Castaway's brothel is taken over by the 'Sapphists'. 
El sueño de Venencia presented a timely corrective to Spanish historiography through a shifting exploration of a range of literary genres, most notably the picaresque. Pointing to the conversa origin of many of the Spanish picaresque heroines, Maria Elena Soliño argues that Díaz-Mas' picara subverts picaresque convention from within, by puncturing or at least unsettling the illusion of male authorship, and of received histories. ${ }^{37}$ At the genre's very origins, interstices and the unsaid have given rise to speculation, whether in Lazarillo de Tormes' 'otras cosillas que no digo', or the glancing details of Lazaro's wife's infidelities, hints appear which are often fleshed out in later editions or in the retelling. The picaresque's association with deviance, the anti-canonical and the untold story, rendered it an appropriate vehicle for the depiction of homosexual desire well before twentieth-century re-tellings. Accepting Anne Cruz's prioritization of La Celestina in the lineage of the female picaresque, there we find 'the old bawd's' appreciation of, and indeed desire for the young female body voiced openly. ${ }^{38}$ Velasco has noted an expression of same sex desire in Chapter 4 of La Lozana andaluza. ${ }^{39}$ Catalina de Erauso's entire life story as later told in Historia de la Monja Alférez, Catalina de Erauso, escrita por ella misma(1829) is one of nonconformity either to gender roles or prescribed modes of desire. ${ }^{40}$ More explicit expressions of lesbian desire become a feature of eighteenth-century picaresque texts in the English literary tradition. Daniel Defoe, in particular has always occupied a central role in discussions of the transmission of the picaresque mode into English literature; Antonio Garrido Ardila's recent overview of the development of the genre in Europe classifies Moll Flanders (1722) as the first British picaresque novel. He notes that in Defoe's Roxana (1724) there are hints of an intimate relationship between the eponymous

37 María Elena Soliño, 'Revealing Beauty/Revealing History in El sueño de Venecia', Hispanic Review, 76:4 (2008), 335-59.

38 Juan Pedro Gabino describes the episode as follows: 'Celestina se presenta ante Areúsa como "una enamoradora tuya”, mira su desnudez con gozo y tienta a la joven con la excusa de inspeccionar sobre el dolor de matriz de esta, al par que lanza loas sobre el cuerpo lozano aquel con inefable delectación’ (Juan Pedro Gabino, 'Erotología femenina en la literatura medieval castellana’, in Los territorios literarios de la historia del placer, ed. José Antonio Crezo, Daniel Eisenberg \& Víctor Infantes [Madrid: Huera y Fierro Editores, 1996], 91-105 [p.100]).

39 Sherry Velasco, Lesbians in Early Modern Spain (Nashville: Vanderbilt U. P., 2011), 63-64.

40 On 'The Lieutenant Nun’ as depicted on the early modern stage and page, see Velasco, Lesbians in Early Modern Spain, 70-83, and The Lieutenant Nun: Transgenderism, Lesbian Desire, and Catalina de Erauso (Austin: Univ. of Texas Press, 2000). Velasco points out that Erauso is referenced in Alonso de Castillo Solórzano’s picaresque novel of 1637 Aventuras del Bachiller Trapaza as part of a scheme to make money from the celebrity of this singular figure by impersonating her (p. 64). The Lieutenant Nun, p.64. 
protagonist and Amy. ${ }^{41}$ More explicitly, in John Cleland's Memoirs of a Lady of Pleasure or Fanny Hill (1748-9), Fanny is initiated in tribadism by the more experienced Phoebe. With her interest in erotic fiction, it seems at least possible that Vicente might have encountered the translation of Fanny Hill which was published in Buenos Aires in 1900, well before such a text appeared in Spain. ${ }^{42}$

Analysing recent trends in contemporary fiction, Felski acknowledges the reappearance of the form:

In recent years a new form of lesbian fiction has appeared on the literary scene, a heady blend of cynicism and sex, urban sleaze and everyday anomie. What few people seem to have noticed is that we are seeing the resurgence of a very old plot pattern, newly updated and refurbished for the present: the picaresque. ${ }^{43}$

Zezé would seem to be constrained by her presence within a picaresque, which holds out the promise of social mobility only to deny it, by her profession with its objectifying gaze, and by the limitations of contemporary representation of women who desire women. However she seizes the opportunity for self-representation to a new audience. In keeping with the undertow throughout the text it ends on the prospect of a sequel-Zezé y yo (diálogos) which promises to be as provocative as the controversial double acts causing a stir in the theatre in the first decade of the twentieth century. ${ }^{44}$

41 'The Girl lov'd me to an Excess, hardly to be describ'd', 'We talk'd it over sometimes in-Bed, almost whole Nights together'. Ardila also highlights a passage wherein Roxana praises Amy's beauty and then insinuates 'the rest was to us only that knew of it' (Juan Antonio Garrido Ardila, La novela picaresca en Europa, 1554-1753 [Madrid: Visor, 2009], 190).

42 John Cleland, Memorias de Fanny Hill (Buenos Aires: Talleres Gráficos, 1900).

43 Felski, Literature after Feminism, 110.

44 We find the promise of a sequel (which fails to materialize) in Quevedo's El Buscón and later in the female picaresque, in La pícara Justina and Teresa de Manzanares. 